\title{
STRES KERJA DITINJAU DARI KECERDASAN SPIRITUAL PADA PERAWAT
}

\author{
WORK STRESS VIEWED FROM SPIRITUAL INTELLIGENCE IN NURSES
}

\author{
Oleh: \\ Iga Niza Kartika Caniago ${ }^{1}$ \\ Winida Marpaung ${ }^{2}$ \\ Rina Mirza ${ }^{3}$
}

\begin{abstract}
Submitted:

30 Oktober 2019

Revision:

10 Januari 2020

26 Januari 2020

Accepted:

16 Januari 2020

This study aims to determine the relationship between spiritual intelligence and work stress. The research subjects used in this study were nurses at Royal Prima Hospital in Medan of 110 people who were selected using purposive sampling. Analysis of the data used is to use Product Moment Analysis through SPSS 17 for Windows. The results of data analysis showed $r=-0.329$ and $p=0.000(p<0.05)$ which indicates that there is a negativerelationship between spiritual intelligence and work stress. The results of this study indicate that the contribution $\left(R^{2}\right)$ given the variablespiritual intelligence for work stress is equal to 10.9 percent, the remaining 89.1 percent is influenced by other factors not examined. From the results of this study it can be concluded that there is a negativerelationship between spiritual intelligence and work stress, assuming the higherspiritual intelligence, the lower work stress and vice versa the lower spiritual intelligence, the higher work stress.
\end{abstract}

Keywords: Nurses; Spiritual Intelligence; Work Stress.

\begin{abstract}
ABSTRAK
Penelitian ini bertujuan untuk mengetahui hubungan antara kecerdasan spiritual dengan stres kerja. Subjek penelitian yang digunakan dalam penelitian ini adalah perawat RSU Royal Prima di Medan sebanyak 110 orang yang dipilih dengan menggunakan purposive sampling. Analisis data yang digunakan adalah menggunakan Analisa Product Moment melalui bantuan SPSS 17 for Windows. Hasil analisis data menunjukkan $\mathrm{r}=-0.329$ dan $\mathrm{p}=0.000(\mathrm{p}<0.05)$ yang menunjukkan bahwa terdapat hubungan negatif antara kecerdasan spiritual dengan stres kerja. Hasil penelitian ini menunjukkan bahwa sumbangan $\left(\mathrm{R}^{2}\right)$ yang diberikan variabel kecerdasan spiritual terhadap stres kerja sebesar 10.9 persen, selebihnya 89.1 persen dipengaruhi oleh faktor lain yang tidak diteliti. Hasil penelitian ini dapat ditarik kesimpulan bahwa ada hubungan negatif antara kecerdasan spiritual dengan stres kerja, dengan asumsi semakin tinggi kecerdasan spiritual maka semakin rendah stres kerja, dan sebaliknya semakin rendah kecerdasan spiritual maka semakin tinggi stres kerja.
\end{abstract}

Kata kunci: Kecerdasan Spiritual; Stres Kerja; Perawat.

\section{PENDAHULUAN}

Kesehatan adalah hal yang sangat penting bagi semua manusia karena tanpa kesehatan yang baik, maka akan sulit untuk melakukan aktivitas sehari-hari. Kesehatan merupakan keadaan (status) sehat utuh secara fisik, mental (rohani) dan sosial, dan bukan hanya suatu keadaan yang bebas dari penyakit, cacat dan kelemahan. Seperti yang dikemukakan oleh Parson (dalam Asmadi, 2005) sehat adalah kemampuan optimal individu untuk menjalankan peran dan tugasnya secara efektif.

Sistem kekebalan tubuh atau imun sangatlah berperan penting untuk menjaga daya tahan tubuh agar selalu fit dan bugar. Salah satu cara menjaga agar tubuh tetap dalam keadaan 
sehat adalah dengan gaya hidup yang bersih dan sehat. Karena mencegah penyakit lebih baik daripada mengobati. Seperti yang kita ketahui penyakit bisa menyerang kapan saja dan dimana saja, tidak mengenal tua maupun yang masih muda dan ketika individu diserang penyakit, keinginan untuk memperoleh perawatan dan pelayanan yang baik akan didambakan. Individu akan mencari kesembuhan yaitu menemui jasa pelayanan kesehatan tanpa peduli dengan biaya yang akan dikeluarkan (McKenzie, Pinger, \& Kotecki, 2006).

Pelayanan kesehatan yang diakui di Indonesia salah satunya adalah rumah sakit. Siregar (2003) mengatakan rumah sakit merupakan suatu organisasi yang kompleks, menggunakan gabungan alat ilmiah khusus dan rumit, dan difungsikan oleh berbagai kesatuan personel terlatih dan terdidik dalam menghadapi dan menangani masalah medik modern, yang semua nya terikat bersama-sama dalam maksud yang sama, untuk pemulihan dan pemeliharaan kesehatan yang baik. Berdasarkan Keputusan Menteri Kesehatan Nomor 983/1992 (dalam Jayanti, 2009) rumah sakit adalah sarana upaya kesehatan yang menyelenggarakan kegiatan kesehatan serta dapat dimanfaatkan untuk kepentingan pendidikan tenaga kesehatan dan penelitian. Oleh karena itu rumah sakit dituntut untuk selalu siap siaga dalam keadaan apapun itu untuk memberikan pelayanan yang terbaik kepada masyarakat.

Setiap rumah sakit juga memiliki tugas dan fungsi yang harus dijalankan untuk keberlangsungan aktivitas rumah sakit tersebut, adapun tugas rumah sakit adalah melaksanakan upaya kesehatan secara berdaya guna dan berhasil guna dengan mengutamakan upaya penyembuhan dan pemeliharaan yang dilaksanakan secara serasi dan terpadu dengan upaya peningkatan dan pencegahaan serta melaksanakan rujukan. Siregar (2003) mengatakan rumah sakit mempunyai berbagai fungsi, yaitu menyelenggarakan pelayanan medik, pelayanan penunjang medik dan nonmedik, pelayanan dan asuhan keperawatan, pelayanan rujukan, pendidikan dan pelatihan, penelitian dan pengembangan, serta administrasi umum dan keuangan. Semua tugas dan fungsi tersebut harus dilakukan oleh para tenaga medis terutama perawat, karena perawat memiliki tanggung jawab yang besar di setiap rumah sakit.

Perawat kesehatan memegang peranan penting dalam rumah sakit karena berhubungan langsung dengan pasien. Dalam menjalankan peraktik keperawatan harus senantiasa meningkatkan mutu pelayanan profesinya, dengan mengikuti perkembangan ilmu pengetahuan dan teknologi melalui pendidikan dan pelatihan sesuai dengan bidang dan tugasnya. Dalam melaksanakan praktik keperawatan, perawat juga dituntut melakukan peran dan fungsi sebagaimana yang diharapkan oleh profesi dan masyarakat sebagai pengguna jasa pelayanan keperawatan.

Peran perawat merupakan tingkah laku yang diharapkan oleh orang lain terhadap seseorang. Menurut Doheny (dalam Kusnanto, 2003) ada beberapa peran perawat, yaitu sebagai pemberi asuhan keperawatan (care giver), sebagai pembela untuk melindungi klien (client advocate), sebagai pemberi bimbingan/konseling klien (counsellor), sebagai pendidik klien (educator), sebagai anggota tim kesehatan yang dituntut untuk dapat bekerja sama dengan tenaga kesehatan lain (collaborator), sebagai koordinator agar dapat memanfaatkan sumbersumber dan potensi klien (coordinator), sebagai pembaru yang selalu dituntut untuk mengadakan perubahan-perubahan (change agent), sebagai sumber informasi yang dapat membantu memecahkan masalah klien (consultant).

Peranan sebagai perawat tersebut akan memberikan banyak efek terhadap si perawat itu sendiri. Apabila perawat tidak mampu menghadapi semua permasalahan dan kendalakendala yang terjadi, maka akan berdampak negatif bagi perawat dan dapat mengganggu aktivitasnya dalam melakukan tugasnya. Selain harus berhadapan dengan tuntutan-tuntutan dari pasien, perawat juga harus menghadapi tuntutan dari atasan.

Kondisi tersebut yang menyebabkan perawat menjadi salah satu target dari rumah sakit yang ingin ditingkatkan kompetensinya karena kualitas kerja perawat mempengaruhi tingkat kepercayaan pasien pada suatu rumah sakit. Seorang perawat mempunyai tugas dan tanggung 
jawab memperjuangkan keselamatan jiwa pasien, sehingga perawat dituntut selalu sigap dan tanggap untuk membantu pasien yang membutuhkan pertolongan dan penanganan medis, karena itu pekerjaannya menuntut ketahanan kerja yang tinggi.

Ada beberapa masalah yang terjadi kepada perawat di Indonesia. Kasus pertamaterjadi pada ratusan perawat di Rumah Sakit Umum Pusat (RSUP) Haji Adam Malik. Kasus ini terjadi pada 2 September 2013, mereka menolak beban kerja yang diberikan manajemen rumah sakit. Koordinator aksi Martoni Calvin, menyatakan aksi ini mereka lakukan karena merasa beban kerja yang diberikan melebihi ketentuan. Kondisi saat ini seorang perawat harus menjaga begitu banyak pasien, 1 banding 16 pasien, padahal sesuai ketentuan maksimal 1 banding 6 pasien. Kami minta dipekerjakan sesuai porsi, ujar Calvin. Mereka meminta manajemen rumah sakit untuk memperhatikan keluhan mereka dan segera memperbaiki kondisi yang meresahkan itu. Mereka juga mengancam akan melakukan aksi mogok kerja jika hal ini tidak segera diselesaikan (Detik.com, 2013).

Kasus di atas sejalan dengan kasus yang dialami oleh perawat RSU Royal Prima di Medan. Berdasarkan hasil wawancara yang dilakukan kepada beberapa orang perawat, mereka mengatakan bahwa terkadang merasa tertekan saat bekerja. Seperti beberapa perawat yang bekerja di bagian rawat inap, dimana saat menerima keluhah-keluhan dari pasien, para perawat terkadang mau marah karena tidak sabar melihat pasien yang suka mengeluh. Para perawat juga mengatakan kalau beban dari pekerjaan yang mereka lakukan tidak sesuai dengan hasil yang mereka terima. Seperti untuk kehadiran, dari pihak pengelola rumah sakit tidak ada dispensasi, terlambat satu menit saja mereka mendapat potongan gaji. Perawat sering mengeluhkan hal tersebut, terkadang kondisi ini membuat perawat ingin keluar dari pekerjaannya. Perawat lainnya juga mengatakan bahwa mereka terkadang merasa cemas, bingung dan panik saat menangani pasien yang kondisinya sedang kritis. Hal tersebut terjadi karena menurut mereka bahwa mereka akan berhadapan dengan hidup matinya seseorang dan itu menjadi beban yang berat buat mereka sebagai seorang perawat.

Beehr dan Newman (dalam Wijono, 2010), mengatakan bahwa stres kerja merupakan suatu keadaan yang timbul dalam interaksi diantara manusia dengan pekerjaan. Sedangkan menurut Mangkunegara (2013) stres kerja sendiri adalah suatu perasaan tertekan yang dialami karyawan dalam menghadapi pekerjaan.

Selye (dalam Umam, 2012) juga mengungkapkan bahwasanya stres kerja dapat diartikan sebagai sumber atau stressor kerja yang menyebabkan reaksi individu berupa reaksi fisiologi, psikologis, dan perilaku. Sejalan dengan itu French., dkk (dalam Wijono, 2010), mendefinisikan stres kerja sebagai ketidakcocokan antara keterampilan dan kemampuan seseorang dan tuntutan pekerjaan yang salah dalam hal kebutuhan seseorang yang disediakan oleh lingkungan kerja.

Menurut Wijono (2010) ada beberapa gejala dari stres kerja, yaitu terdiri dari: (a) Perubahan fisiologis yang ditandai oleh adanya gejala-gejala seperti merasa letih/lelah, kehabisan tenaga, pusing, gangguan pencernaan; (b) Perubahan psikologis yang ditandai oleh adanya kecemasan berlarut-larut, sulit tidur, nafas tersengal-sengal; (c) Perubahan sikap seperti keras kepala, mudah marah, tidak puas terhadap apa yang dicapai, dan sebagainya.

Tama dan Hardiningtyas (2017) mengungkapkan ada empat jenis stres kerja yaitu: (a) Eustress, merupakan stres positif yang bisa memunculkan usaha-usaha yang kreatif; (b)Distress, merupakan jenis stres negatif, yang umumnya terjadi saat ketika pikiran tidak nyaman dengan perubahan dari rutinitas dan sangat membutuhkan rutinitas yang lebih familiar; (c) Hyperstress, merupakan stres negatif yang muncul ketika seseorang dipaksa menjalankan lebih dari yang dibutuhkan; (d) Hypostress, sebuah kondisi dimana seseorang yang mengalami kebosanan secara terus-menerus. 
Luthans (dalam Zainal, dkk., 2014) menjelaskan bahwa ada empat hal utama yang menjadi penyebab stres (stressor), diantaranya: (a) Extra organizational stressors, yang terdiri atas perubahan sosial/teknologi, keluarga, relokasi, keadaan ekonoi dan keuangan, ras dan kelas, serta keadaan komunitas/tempat tinggal; (b) Organizational stressors, yang terdiri atas kebijakan organisasi, struktur organisasi, keadaann fisik dalam organisasi, dan proses yang terjadi didalam organisasi; (c) Group stressors, yang terdiri atas kurangnya kebersamaan dalam grup, kurangnya dukungan sosial, serta adanya konflik intraindividu, interpersonal, dan intergrup; (d) Individual stressors, yang terdiri atas terjadinya konflik dan ketidakjelasan peran, serta disposisi individu, seperti pola kepribadian tipe A, kontrol personal, learned helplessness, self-efficacy, dan daya tahan psikologis.

Salah satu faktor yang mempengaruhi stres kerja adalah kecerdasan spiritual. Sebagaimana penelitian yang dilakukan oleh Marzabadi, Hoshmandja, dan Poorkhalil (2013) yang berjudul the relationship between personnel's job stress and their spiritual intelligence and organizational spirituality in a military university. Penelitian tersebut menyatakan bahwa ada korelasi negatif yang signifikan antara kecerdasan spiritual dengan stres kerja yang berarti semakin tinggi kecerdasan spiritual maka semakin rendah tingkat stres kerja. Begitu pula sebaliknya, semakin rendah kecerdasan spiritual maka semakin tinggi tingkat stres kerja pada personil di Universitas Militer Iran.

Tasmara (dalam Wahab \& Umiarso, 2011) mengatakan bahwa kecerdasan spiritual adalah kemampuan seseorang untuk mendengarkan hati nuraninya, baik buruk dan rasa moral dalam caranya menempatkan diri dalam pergaulan. Wigglesworth (dalam Asteria, 2014) menyatakan bahwa kecerdasan spiritual merupakan kemampuan untuk dapat melakukan sesuatu dengan penuh kasih sayang dan bijaksana, sembari menata diri dari dalam dan luar dengan penuh ketenangan hati dalam segala keadaan.

Menurut Azzet (2011) kecerdasan spiritual merupakan kecerdasan yang mengangkat fungsi jiwa sebagai perangkat internal diri yang memiliki kemampuan dan kepekaan dalam melihat makna yang ada dibalik sebuah kenyataan atau kejadian tertentu. Kecerdasan spiritual terkait erat dengat kemampuan yang berujung pada pencerahan jiwa. Orang yang mempunyai kecerdasan spiritual yang baik akan mampu memaknai secara positif pada setiap peristiwa, masalah bahkan penderitaan yang dialaminya. Dengan memberikan makna yang positif itu, maka seseorang akan mampu membangkitkan jiwanya dan melakukan perbuatan dan tindakan yang positif.

Tirri dan Nokelainen (2011) menyatakan kecerdasan spiritual memiliki empat dimensi yaitu: (a) Awereness Sensing, pengalaman di tingkat yang lebih dalam kesadaran ketika kita memilih untuk menjadi sadar dengan memperhatikan apa yang terjadi disekitar kita; (b) Mystery Sensing, kemampuan kita untuk mengatasi pengalaman sehari-hari dan menggunakan imajinasi kita; (c) Value Sensing, menekankan pentingnya perasaan sebagai ukuran apa yang kita nilai; (d) Community Sensing, terbagi menjadi tiga, yaitu human spirituality, devotional spirituality, practical spirituality.

\section{METODE PENELITIAN}

Variabel yang terlibat pada penelitian ini adalah kecerdasan spiritual sebagai variabel bebas dan stress kerja sebagai variabel terikat. Subjek dalam penelitian ini adalah110 orang perawatRumah Sakit Umum Royal Prima di Medan. Teknik pengambilan sampel yang digunakan untuk penelitian ini adalah Purposive Sampling.

Metode pengumpulan data yang digunakan dalam penelitian ini menggunakan metode pembagian skala untuk mengukur stres kerja dan kecerdasan spiritual. Jenis skala yang digunakan adalah skala Likert. 
Skala stress kerja dalam penelitian ini disusun berdasarkan simtom yang dikemukakan oleh Wijono (2010) yaitu: perubahan psikologis, perubahan fisiologi, dan perubahan perilaku. Skala stres kerja ini berjumlah 23 aitem dengan daya gerak dari 0.309-0.710 dengan estimasi reliabilitas alpha sebesar 0.899. Skala kecerdasan spiritual dalam penelitian ini disusun berdasarkan dimensi yang dikemukakan oleh Tirri dan Nokelainen (2011) diantaranya, yaitu: awereness sensing, mystery sensing, value sensing, community sensing. Skala kecerdasan spiritual ini berjumlah 32 aitem dengan daya gerak dari 0.300-0.822 dengan estimasi reliabilitas alpha sebesar 0.955 .

Teknik analisis yang digunakan untuk menguji hipotesis sekaligus menganalisis data hasil penelitian ini adalah dengan menggunakan metode korelasi Product Moment (Pearson Corellation).

\section{HASIL DAN PEMBAHASAN}

Analisis data dilakukan dengan menggunakan SPSS 17 for windows. Sebelumnya dilakukan uji asumsi yang berupa uji normalitas data dan uji liniearitas

Tabel 1.

Hasil Uji Normalitas

\begin{tabular}{lccccc}
\hline Variabel & Mean & $\begin{array}{c}\text { Standar } \\
\text { Deviasi }\end{array}$ & KS-Z & Sig & Keterangan \\
\hline $\begin{array}{l}\text { Stres } \\
\text { Kerja }\end{array}$ & 49,80 & 6,659 & 0,980 & $0,292>0,05$ & Normal \\
\hline $\begin{array}{l}\text { Kecerdasan } \\
\text { Spiritual }\end{array}$ & 101,32 & 12,745 & 1,082 & $0,192>0,05$ & Normal \\
\hline
\end{tabular}

Uji normalitas dilakukan agar dapat mengetahui apakah setiap variabel penelitian telah menyebar secara normal atau tidak. Uji normalitas sebaran menggunakan uji Kolmogorov Smirnov Test. Data dikatakan berdistribusi normal jika $\mathrm{p}>0.05$ (Priyatno, 2010). Uji normalitas yang dilakukan terhadap variabel stres kerja diperoleh koefisien $\mathrm{KS}-\mathrm{Z}=0.980$ dengan Sig sebesar 0.292 untuk uji 2 (dua) arah dan Sig sebesar 0.146 untuk uji 1 (satu) arah ( $p>0.05$ ),yang berarti bahwa data pada variabel stres kerja memiliki sebaran atau berdistribusi normal.Uji normalitas pada variabel kecerdasan spiritual diperoleh koefisien $\mathrm{KS}-\mathrm{Z}=1.082$ dengan Sig sebesar 0.192 untuk uji 2 (dua) arah danSig sebesar 0.96 untuk uji 1 (satu) arah (p $>0.05$ ), yang berarti bahwa data pada variabel kecerdasan spiritual memiliki sebaran atau berdistribusi normal.

Tabel 2.

Hasil Uji Linearitas Hubungan

\begin{tabular}{lccc}
\hline \multicolumn{1}{c}{ Variabel } & F & Sig & Keterangan \\
\hline Stres Kerja & 17.204 & 0.000 & Linear \\
Kecerdasan Spiritual & & & \\
\hline
\end{tabular}

Berdasarkan tabel 2. dapat dikatakan bahwa variabel stres kerja dan kecerdasan spiritual memiliki hubungan linear. Hal ini terlihat dari nilai sig yang diperoleh yaitu 0.000 maka $\mathrm{p}<0.05$, dapat disimpulkan bahwa kedua variabel memiliki hubungan linear dan telah memenuhi syarat untuk dilakukan analisa korelasi Product Moment. 
Hasil penelitian pada 110 perawat Rumah Sakit Umum Royal Prima di Medan yang menjadi subjek penelitian, diperoleh hasil bahwa ada hubungan antara kecerdasan spiritual dengan stres kerja dengan koefisien korelasi Product Moment sebesar $\mathrm{r}=-0.329$ dan nilai $\mathrm{p}=$ 0.000 ,artinya semakin tinggi kecerdasan spiritual maka semakin rendah stres kerja, dan sebaliknya semakin rendah kecerdasan spiritual maka semakin tinggi stres kerja.

Menurut Azzet (2015) persoalan kejiwaan, seperti cemas, kebingungan, kehilangan orientasi, hidup terasa hampa, stres, insomnia, bahkan putus asa begitu mudah terjadi saat mulai kehilangan spiritualitas. Terkait hal tersebut, Anoraga (2006) mengatakan dalam kehidupan modern yang semakin kompleks, manusia akan cenderung mengalami stres apabila kurang mampu mengadaptasi keinginan-keinginan dengan kenyataan-kenyataan yang ada baik kenyataan yang ada di dalam maupun di luar dirinya. Stres yang dialami seseorang karena pekerjaan akan membuat seseorang merasa tertekan, permasalahan ini yang akan dihadapi oleh setiap orang yang berada dalam dunia kerja. Stres yang terlalu besar dapat mengancam kemampuan seseorang dalam menghadapi lingkungannya. Sebagian orang dapat mengatasi stres yang di alaminya karena pekerjaan dengan berdoa dan beriman kepada Tuhan untuk meningkatkan spiritualnya.

Penelitian ini dilaksanakan pada 110 orang perawat RSU Royal Prima di Medan yang menjadi subjek penelitian, diperoleh hasil bahwa ada hubungan antara kecerdasan spiritual dengan stres kerja dengan koefisien korelasi Product Moment sebesar $\mathrm{r}=-.329$ dan nilai $\mathrm{p}=$ 0.000 , artinya semakin tinggi kecerdasan spiritual maka semakin rendah stres kerja, dan sebaliknya semakin rendah kecerdasan spiritual maka semakin tinggi stres kerja.

Hasil penelitian yang menyatakan adanya hubungan negatif antara kecerdasan spiritual dengan stres kerja sejalan dengan pendapat Umamit dan Mulyani (2016) terhadap perawat di Rumah Sakit Klaten, yang berjumlah 101 orang. Hasil yang diperoleh dari penelitian ini adalah ada hubungan negatif yang sangat signifikan antara kecerdasan spiritual dengan stres kerja pada Perawat Rumah Sakit di Klaten dengan nilai $r=-0.315$ dan $p=0.001(p<0.01)$. Hal tersebut artinya semakin tinggi kecerdasan spiritual maka akan semakin rendah stres kerja dan sebaliknya semakin rendah kecerdasan spiritual maka akan semakin tinggi stres kerja pada perawat.

Penelitian ini juga sejalan dengan penelitian yang dilakukan oleh Salmabi, dkk (2015) terhadap semua guru siswa luar biasa di kota Shahriar, yang berjumlah 120 orang. Hasil yang diperoleh dari penelitian ini adalah ada hubungan negatif yang signifikan antara kecerdasan spiritual dengan stres kerja pada guru siswa luar biasa di kota Shahriar, yang artinya semakin tinggi kecerdasan spiritual maka akan semakin rendah stres kerja dan sebaliknya semakin rendah kecerdasan spiritual maka akan semakin tinggi stres kerja.

Pada penelitian ini diperoleh koefisien determinasi $R$ Square $\left(\mathrm{R}^{2}\right)$ sebesar 0.109. Berdasarkan hasil tersebut dapat disimpulkan bahwa 10.9 persen kecerdasan spiritual mempengaruhi stres kerja dan 89.1 persen dipengaruhi oleh faktor lain, seperti konflik peran ganda, religiusitas, efikasi diri, dan kepuasan kerja.

Penelitian ini menunjukkan bahwa terdapat 27 subjek dengan persentase sebesar 24.6 persen yang memiliki tingkat stres kerja rendah, terdapat 83 subjek dengan persentase sebesar 75.4 persen yang memiliki tingkat stres kerja sedang, dan tidak ada subjek yang memiliki tingkat stres kerja tinggi. Berdasarkan penjelasan di atas maka dapat disimpulkan bahwa ratarata subjek penelitian memiliki tingkat stres kerja sedang.

Wijono (2010) juga mengungkapkan adanya simtom psikologis dengan indikator kecemasan berlarut-larut, bahwa peneliti menemukan pernyataan yang sesuai dengan simtom dari para perawat yang berada di RSU Royal Prima Medan. Berdasarkan kategori rendah 24.6 persen perawat dengan stres kerja rendah, berdasarkan kategori sedang 75.4 persen perawat dengan kategori sedang. Disimpulkan dari hasil observasi dan wawancara dari beberapa perawat tersebut menyatakan mereka sering merasa tegang dan panik saat menghadapi pasien 
yang sedang kritis dan juga dikarenakan beban kerja yang berlebihan yang mereka rasakan di rumah sakit tersebut.

Selanjutnya, pada simtom fisiologis para perawat yang berkerja di rumah sakit tersebut sering mengalami kelelahan dan kehabisan tenaga dalam bekerja seharian dan menghadapi banyak pasien. Dapat disimpulkan bahwa para perawat di RSU Royal Prima Medan memiliki tingkat stres kerja yang sedang dengan persentase 75.4 dikarenakan subjek merasa mereka harus tetap sabar bagaimanapun pasien yang mereka tangani, karena sudah menjadi kewajiban subjek dalam merawat dan membantu pasien yang ada di rumah sakit tersebut. Sedangkan perawat yang memiliki tingkat stres kerja rendah dengan persentase 24.6 dikarenakan subjek dengan senang hati melakukan pekerjaannya.

Penelitian ini juga meneliti tingkat kecerdasan spiritual perawat RSU Royal Prima Medan. Hasil menunjukkan tidak ada subjek dengan tingkat kecerdasan spiritual yang rendah, selain itu terdapat 34 subjek dengan persentase 31 persen yang masuk dalam kategori sedang serta sebanyak 76 subjek dengan persentase 69 persen yang masuk dalam kategori yang tinggi. Berdasarkan penjelasan diatas maka dapat disimpulkan bahwa rata-rata subjek penelitian memiliki tingkat keterampilan sosial yang sedang.

Berdasarkan hasil observasi dan wawancara terhadap beberapa perawat RSU Royal Prima Medan dengan tingkat kecerdasan spiritual sedang sebanyak 34 subjek dengan persentase 31 persen memiliki kecerdasan spiritual yang cukup baik. Hal ini terlihat dari tingkat kesadaran para perawat dalam memperhatikan apa yang terjadi disekitarnya. Walaupun mereka sedang sibuk karena banyaknya pekerjaan yang harus dilakukan, tetapi mereka tetap memperhatikan rekan kerja mereka.

Terdapat juga 76 subjek dengan persentase 69 persen yang masuk dalam kategori kecerdasan spiritual tinggi, mereka menyatakan bahwa setiap orang memerlukan kasih sayang dari orang sekitarnya, Karena sebagai makhluk sosial kita juga tidak bisa hidup sendiri, kita saling membutuhkan satu sama lain. Perawat juga mengatakan bahwa setiap orang harus memiliki rasa tanggung jawab akan perbuatannya. Pernyataan tersebut sesuai dengan dimensi kecerdasan spiritual awareness sensing, mystery sensing, value sensing, community sensing.

Pada penjelasan di atas dapat disimpulkan bahwa ada hubungan antara kecerdasan spiritual dengan stres kerja. Semakin tinggi kecerdasan spiritual yang dimiliki oleh seseorang maka semakin rendah pula tingkat stres kerjanya. Sebaliknya, semakin rendah kecerdasan spiritual yang dimiliki oleh seseorang maka semakin tinggi pula tingkat stres kerjanya.

\section{KESIMPULAN}

Kesimpulan dari penelitian ini ada hubungan negatif antara kecerdasan spiritual dengan stres kerja pada perawat RSU Royal Prima di Medan, artinya semakin tinggi kecerdasan spiritual seseorang, maka stres kerja akan semakin rendah, dan sebaliknya jika semakin rendah kecerdasan spiritual seseorang, maka stres kerja akan semakin tinggi.

Saran bagi perawat agar dapat mereduksi tingkat stres kerja yang mereka rasakan dengan mengembangkan emotional focused coping yang bertujuan untuk mengontrol respon emosional terhadap situasi stres. Seperti merelaksasikan diri, terlibat dalam aktivitas olahraga yang dapat mengalihkan seseorang dari masalahnya, mencari dukungan sosial yaitu dengan menceritakan permasalahannya pada orang terdekat diantaranya rekan kerja saat menghadapi tekanan dalam pekerjaan sehingga dapat mengurangi beban yang dirasakan sehingga dapat menurunkan tingkat stres dialami. Memberikan penilaian positif terhadap sumber masalah atau situasi yang dihadapi. Saran bagi peneliti selanjutnya diharapkan dapat meneliti faktor lain 
yang lebih mendukung variabel-variabel dalam penelitian ini seperti seperti efikasi diri, konflik peran ganda, kepuasan kerja, dan religiusitas untuk diteliti.

\section{DAFTAR PUSTAKA}

Anoraga, P. (2006). Psikologi kerja. Jakarta: PT Rineka Cipta.

Asmadi. (2005). Konsep dasar keperawatan. Jakarta: Penerbit Buku Kedokteran EGC.

Asteria, P. V. (2014). Mengembangkan kecerdasan spiritual anak melalui pembelajaran membaca sastra. Malang: UB Press.

Azzet, A. M. (2011). Mengembangkan kecerdasan sosial bagi anak. Jogjakarta: Katahati.

Azzet, A. M. (2015). Mengembangkan kecerdasan spiritual bagi anak. Jogjakarta: Katahati.

Jayanti, N.K.I. (2009). Penyelesaian hukum dalam malapraktik kedokteran. Jakarta: PT Buku Kita.

Kustanto. (2003). Pengantar profesi dan praktik keperawatan profesional. Jakarta: buku kedokteran EGC.

Mangkunegara, A. P. (2013). Manajemen sumber daya manusia perusahaan. Bandung: Remaja Rosdakarya

Marzabadi, A. E., Hoshmandja \& Poorkhalil. (2013). The relationship between personnel's job stress and their spiritual intelligence and organizational spirituality in a military university. Iranian Journal of Military Medicine, 15, 45-52.

McKenzie, J. F., Pinger, R. R \& Kotecki, J. E. (2006). Kesehatan masyarakat. Jakarta: EGC.

Salmabi, M., Farshad, M. R., Bajestani, H. S \& Alikhani, M. (2015). Prediction of job stress based on spiritual intelligence and self-differentiation. Health, Spirituality And Medical Ethics, 2, 2-8.

Siregar, C. J. P. (2003). Farmasi rumah sakit: teori dan penerapan. Jakarta: Buku Kedokteran EGC.

Tama, I. P \& Hardiningtyas, D. (2017). Psikologi industri: dalam perspektif sistem industri. Malang: UB Pres.

Tirri, K \& Noekelainen, P. (2011). Measuring multiple intelligences and moral sensistivities ineducation. Rotterdam: Sense Publishers.

Umam, k. (2012). Perilaku organisasi. Bandung: CV. Pustaka Setia.

Umamit, R \& Mulyani, s. (2016). Hubungan antara kecerdasan spiritual dengan stres kerja pada perawat rs di klaten. Psikologika, 21.

Wahab \& Umiarso. (2011). Kepemimpinan pendidikan dan kecerdasan spiritual. Jogjakarta:Ar -Ruzz Media. 
Wijono, S. (2010). Psikologi industri dan organisasi: dalam suatu bidang gerak psikologi sumber daya manusia. Jakarta: Prenada Media Group.

Zainal, V. R., Hadad, D \& Ramly, M. (2014). Kepemimpinan dan perilaku organisasi. Jakarta: PT Raja Grafindo Persada.

Detik.com. (2013). Ratusan perawat berdemo di rumah sakit umum pusat (rsup) haji adam malik, medan, mereka menolak beban kerja yang diberikan manajemen rumah sakit. Diakses pada tanggal 23 September 2018, dari https://news.detik.com/berita/2346744/ratusan-perawat-rsup-haji-adam-malik-medan -demo-tolak-kerja-berlebih 